Vol 11, Issue 11, 2018

\title{
ELTROXIN LIKE MIMIC ACTION OF WITHANIA SOMNIFERA LEAF EXTRACT IN HYPOTHYROID-INDUCED RATS
}

\author{
ABHILASHA PUROHIT*, ASHOK PUROHIT \\ Department of Zoology, Jai Narain Vyas University, Jodhpur, Rajasthan, India. Email: abhilashapurohit25@gmail.com
}

Received: 21 May 2018, Revised and Accepted: 11 July 2018

\begin{abstract}
Objective: The present study was designed to examine the anti-hypothyroid activity of Withania somnifera (Ashwagandha)'s leaf extract on 6-n-propyl2-thio-uracil (PTU) induced hypothyroid rats.

Method: Ethanolic extracts of $W$. somnifera leaf and Eltroxin were administrated to PTU induced hypothyroid rats. The animals were divided into control, PTU treatment, $W$. somnifera leaf extract treatment, and Eltroxin treatment groups for 60 days. The serum $\mathrm{T}_{3}$ and $\mathrm{T}_{4}$ were estimated, and biochemical and hematological parameters of the blood serum were also evaluated.

Results: PTU induction caused a significant decrease $(\mathrm{p} \leq 0.001)$ in $\mathrm{T}_{3}$ and $\mathrm{T}_{4}$ level when compared with the control group. Adverse effects of PTU were also observed in blood sugar, cholesterol, alkaline phosphate, protein, albumin, globulin, liver function test, and renal function test parameters. Nonsignificant changes in LFT,RFT and Other parameters were observed. W.Somnifera's leaf extract and Eltroxin treatment group recovered both of the thyroid hormone secretion as compare to control.
\end{abstract}

Keywords: 6-n-Propyl-2-thio-uracil, Hypothyroid, Withania somnifera, Eltroxin.

(C) 2018 The Authors. Published by Innovare Academic Sciences Pvt Ltd. This is an open access article under the CC BY license (http://creativecommons. org/licenses/by/4. 0/) DOI: http://dx.doi.org/10.22159/ajpcr.2018.v11i11.27424

\section{INTRODUCTION}

Hypothyroidism is one of most the common endocrine disorder [1]. It is defined as a condition when the level of the thyroid hormones decreases below the normal need of the body [2]. The hypothyroidism is a complex hormonal dysfunction rather than a single hormonal defect [3]. Thyroid hormone is a powerful modulator of cardiac function [4]. Hypothyroidism causes the disturbance in body weight and appetite [5]. Even during pregnancy time, a significant change in thyroid hormone metabolism is observed [6]. Synthetic levothyroxine is recommended for hypothyroidism, actually, this drug elevates the $\mathrm{T}_{3}$ and $\mathrm{T}_{4}$ level in blood serum so that thyroid gland activity can be controlled [7]. Whereas, 6-n-propyl-2-thio-uracil (PTU) is prescribed for hyperthyroidism because it can decrease the amount of both thyroid hormones secreted by the thyroid gland [8]. Long duration usage of the synthetic drug can cure the hypothyroidism, but they cause side effects. L-thyroxin can damage the vital organs such as the liver and kidney, and it also causes the reduction in body weight and an increase in the relative body weight of the kidney [9]. Thus, there is a need to develop a drug from plants origin which can work for the hypothyroid treatment. Ayurveda suggests that some plant products cure hypothyroidism and some investigation on the effects of plant products on hypothyroidism is also found. Several bioactive compound has been derived from various plants, having anti-thyroidal activity and low toxicity as compare to synthetic drugs, e.g., :Bamboo shoot [10]. These plant products can control the basal metabolic rate of the body and several cardiovascular diseases like atherosclerosis [11]. These extracts have antioxidants and these can affect the metabolism of the body too [12]. Withania somnifera can effect on antioxidants of animal, and it can increase the serum $\mathrm{T}_{3}$ and $\mathrm{T}_{4}$ significantly. Its roots have a compound name withanolides which can cure many diseases $[13,14]$. Roots of the $W$. somnifera are used in Ayurveda to cure hypothyroidism. This study is designed to evaluate the effect of $W$. somnifera leaf extract on hypothyroidism. Therefore, we have performed an experiment to examine the effect of $W$. somnifera leaf extract on PTU induced hypothyroid rats. This study is aimed to finding out whether $W$. somnifera leaves can increase Serum $\mathrm{T}_{3}, \mathrm{~T}_{4}$ level and affect the thyroid gland activity positively.

\section{METHODS}

\section{Extraction of plant material}

W. sominfera plant's leaves were collected from Jodhpur, Rajasthan state, India, and scientific identification was done in the Department of Botany, Jai Narai Vyas University, Jodhpur. These leaves were extracted with $70 \%$ ethanol for $24-36$ h by Soxhlet extraction method. Then, ethanol was separated under reduced pressure to obtain a blackish dark brown crude residue which was dissolved in distilled water and orally administrated to the animals.

\section{Model animals}

Wistar rats (150-250 g) were purchased from Certified Institute. Protocols for animal care, maintenance and experiments were followed given by Animal Ethical Committee (IAEC, Reg no.: 1646/GO/Re/12/ CPCSEA). For this experiment, 20 female animals were housed in polypropylene cages containing corn-cob bedding and maintained at approximately $25-28^{\circ} \mathrm{F}$ on a 12 -h light/dark cycle. For the animal adaptability, all rats had been fed for 1 week before the experiment. Rats were randomly divided into four groups.

\section{Experimentation \\ Induction of hypothyroidism}

Hypothyroidism was induced in euthyroid rats by administration of PTU at the dose of $10 \mathrm{mg} / \mathrm{kg}$ in drinking water as well as orally for 30 days.

\section{Dose regime of Eltroxin}

Eltroxin was used as a standard drug to cure hypothyroid that was orally administrated at the dose of $0.5 \mu \mathrm{g} / 100 \mathrm{~g}$ body weight dissolved in $50 \mathrm{~mL}$ of distilled water. 


\section{Preparation of plant drug}

The $70 \%$ ethanolic extract (500 mg/kg.b.wt.) was prepared then given to the experimentally induced hypothyroid rats.

\section{Experimental design}

The experimental period comprised 60 days and the rats were divided into the following groups $(n=5)$.

- Group I: Intact control: Rats receiving normal slandered rat pallets with saline water.

- Group II: Hypothyroid control: Rats were orally injected PTU for hypothyroidism induction for 60 days.

- Group III: W. somnifera leaf extract's treatment group: PTU treated rats received $W$. somnifera leaf extracts (70\% ethanolic extracts) for next 30 days on the dose of $500 \mathrm{mg} / \mathrm{kg}$ body weight.

- Group IV: Eltroxin treatment group: PTU treated rats received Eltroxin at the dose of $0.5 \mu \mathrm{g} / 100 \mathrm{~g}$ body weight for the next 30 days.

\section{Serum biochemistry}

At the end of the experiment, all rats were sacrificed under prolonged anesthesia and blood was collected through the direct cardiac puncture. Serum was separated and stored at $-20^{\circ} \mathrm{C}$ until analyzed.

\section{Assessment of hormone assays of $\mathrm{T}_{3}$ and $\mathrm{T}_{4}$}

Total circulating $\mathrm{T}_{3}$ and $\mathrm{T}_{4}$ in serum were quantitatively determined by enzyme-linked immunosorbent assay following the protocols provided in the CALBIOTECH kits as routinely followed in our laboratory.

\section{Assessment of liver function test (LFT), renal function test (RFT),} and other parameters

For the RFT determination in blood serum urea, creatinine, and uric acid was estimated by the kit method. Whereas serum glutamic oxaloacetic transaminase (SGOT), serum glutamic pyruvic transaminase (SGPT), bilirubin direct, bilirubin indirect, and bilirubin total were measured for the analysis of LFT. Other parameters such as blood sugar, cholesterol, alkaline phosphate, and protein were also evaluated by the kit method. All of these tests were analyzed using Biochem Analyzer RX-50 and commercial diagnostic kits (Siemens Healthcare Diagnostics, USA).

\section{Statistical analysis}

The mean and standard deviation was calculated in terms of mean \pm SEM. One-way analysis of variance was used for parametric analysis of all groups and calculating the statistical differences between the means of the various groups.

\section{Hematology}

Blood was collected by direct cardiac puncture at the end of the experimental period. Collected blood was stored in EDTA vials at $20^{\circ} \mathrm{C}$. Hematological assessments of hemoglobin, TRBC, HCT, MCV, MCH, MCHC, RDW, TLC, PLT, PCT, MPV, and PDW were examined through standard methods [15].

\section{RESULTS}

\section{Hormone assay}

Animals treated by PTU demonstrated significant reduction $(\mathrm{p} \leq 0.001=\mathrm{c})$ in serum level of $\mathrm{T}_{3}$ and slightly significant reduction $(\mathrm{p} \leq 0.05=\mathrm{a}$, in $\mathrm{T}_{4}$ level as compare to control groups whereas $W$. somnifera leaf extracts treated group's blood serum have demonstrated no significant changes in $\mathrm{T}_{3}$ and $\mathrm{T}_{4}$ level as compared to control groups. Moreover, when this Group III was compared to Group II, then it was observed that $T_{3}$ was significantly increase $(\mathrm{p} \leq 0.001=\mathrm{g})$ and $\mathrm{T}_{4}$ had significant changes $(p \leq 0.01=f)$. Eltroxin treatment demonstrated the highly significant changes in $\mathrm{T}_{3}$ level as compared to the control group and no significant changes as compare to PTU group. Actually, $W$. somnifera and Eltroxin, both groups demonstrated the no significant changes in $\mathrm{T}_{4}$ level as compare to control whereas significant changes ( $\mathrm{p} \leq 0.01=\mathrm{f}$.) were observed when compared to PTU treated rats. In both groups, $\mathrm{T}_{4}$ exhibited significance ( $\mathrm{p} \leq 0.01=\mathrm{f})$ (Figs. 1 and 2 ).

\section{Morphological studies}

\section{Body weight and thyroid weight}

No significant changes were observed in body weight in hypothyroid and all treatment groups. No significant changes were observed in relative body weight of liver, pancreas, and heart, although slight reduction in kidney weight was observed in the PTU treatment group as compared to control.

Relative body weight of pancreas, heart, kidney, and liver of Groups III and IV exhibited slightly differences, or no changes as compared to control and PTU treated groups. However, the statistically significant difference was observed in the thyroid weight between Group II (PTU treated Group) and Group I (control group). Whereas, slightly significance or significant changes in relative body weight of thyroid was observed in the next two groups (Groups III and IV) as compared to control and PTU treated groups (Table 1 and Fig. 3).

\section{RFT}

PTU causes some toxicity in kidney which can be observed in RFT parameters where significant, slightly significant, and highly significant changes were evaluated in urea, creatinine, and uric acid values as compared to control group. Whereas W. somnifera leaf extract treatment (Group III) and Eltroxin (Group IV) treatment groups had slightly or no significantly changes in these parameters as compared to control (Table 2).

\section{LFT}

LFT was also affected by PTU in which bilirubin total and bilirubin direct were slightly increased whereas SGOT, SGPT, and bilirubin direct were significantly increased as compared to the control group. However, $W$. somnifera leaf extract and Eltroxin treatment groups also exhibited some changes as compared to the control group (Table 3).

\section{Other parameters}

PTU causes some significant changes in blood, sugar, cholesterol, alkaline phosphate, albumin, and globulin parameters when compared to control group. There is significantly higher blood sugar and

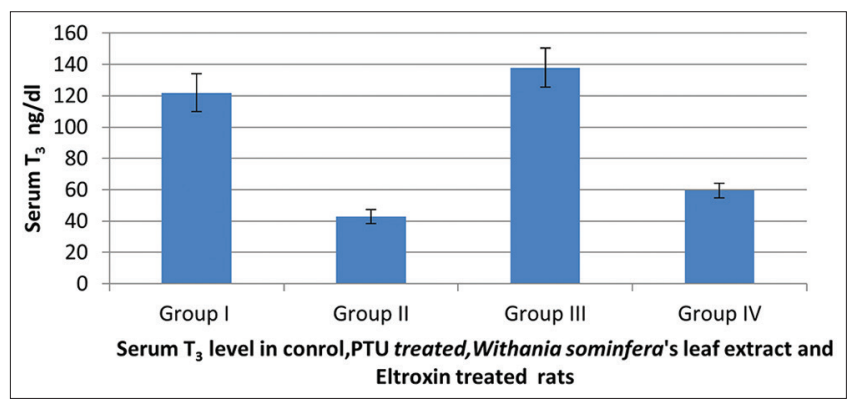

Fig. 1: Effect of Withania somnifera (Ashwagandha) leaf extract on serum $\mathrm{T}_{3}$ in compared to control, 6-n-propyl-2-thio-uracil and Eltroxin treatment groups

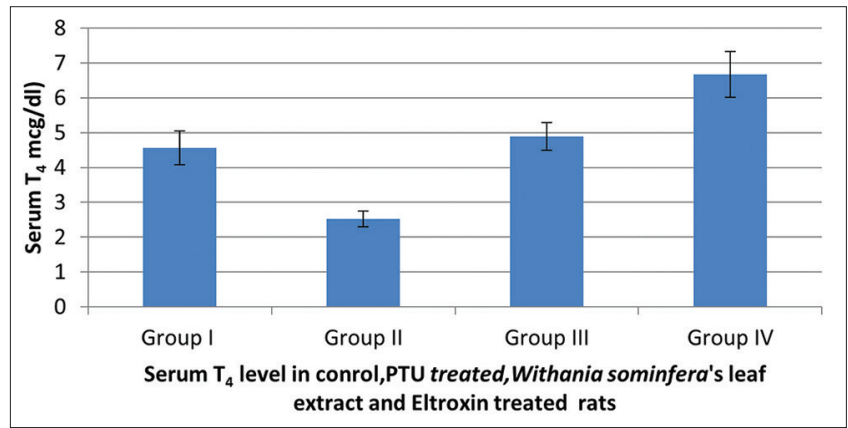

Fig. 2: Effect of Withania somnifera (Ashwagandha) leaf extract on serum $\mathrm{T}_{4}$ in compare to control, 6-n-propyl-2-thio-uracil and Eltroxin treatment groups 
Table 1: Comparative study of body weight and relative body weight of various organs in intact control, PTU treatment, W. somnifera leaf extract treatment and Eltroxin treatment groups

\begin{tabular}{|c|c|c|c|c|c|c|c|}
\hline \multirow[t]{3}{*}{ Group name } & \multirow{2}{*}{\multicolumn{2}{|c|}{$\begin{array}{l}\text { Body weight } \\
\text { In } g\end{array}$}} & \multicolumn{5}{|c|}{ Relative Body Weight } \\
\hline & & & \multicolumn{4}{|c|}{ mg/100 g body weight } & \multirow{2}{*}{$\begin{array}{l}\text { g/100 body } \\
\text { weight } \\
\text { Liver }\end{array}$} \\
\hline & Initial & Final & Thyroid & Pancreas & Heart & Kidney & \\
\hline Group I - intact control & $123.33 \pm 13.33$ & $115 \pm 1128$ & $19.93 \pm 1.87$ & $316.02 \pm 25.4$ & $620.25 \pm 60$ & $990 \pm 90.16$ & $4.31 \pm 0.41$ \\
\hline Group II - PTU treated & $196.66 \pm 18.03$ & $176.66 \pm 13.38$ & $73.87 \pm 6.42^{c}$ & $106.36 \pm 10.95^{\mathrm{d}}$ & $555 \pm 45.75^{d}$ & $890 \pm 8.65^{a}$ & $4.53 \pm 0.34^{\mathrm{d}}$ \\
\hline $\begin{array}{l}\text { GroupIII - W. somnifera } \\
\text { leaf treated }\end{array}$ & $216.66 \pm 16.66$ & $146.66 \pm 13.66$ & $12.31 \pm 1.21^{\mathrm{b}, \mathrm{g}}$ & $258.54 \pm 25.43^{\mathrm{a}, \mathrm{g}}$ & $426.43 \pm 3.954^{\mathrm{a}, \mathrm{e}}$ & $829.58 \pm 52.63^{\mathrm{b}, \mathrm{f}}$ & $3.606 \pm 0.36^{\mathrm{d}, \mathrm{e}}$ \\
\hline GroupIV - Eltroxin & $125 \pm 13$ & $116 \pm 12.88$ & $16.32 \pm 1.65^{\mathrm{a}, \mathrm{g}}$ & $362.43 \pm 21.23^{\mathrm{d}, \mathrm{g}}$ & $570.13 \pm 51.82^{\mathrm{d}, \mathrm{h}}$ & $966.65 \pm 94.42^{\mathrm{d}, \mathrm{e}}$ & $3.87 \pm 0.3^{\mathrm{d}, \mathrm{e}}$ \\
\hline
\end{tabular}

Values expressed as mean \pm SEM (n=5). Groups II-IV compared with Group I, where ${ }^{\mathrm{p} p} \leq 0.05$, ${ }^{\mathrm{b}} \mathrm{p} \leq 0.01,{ }^{\mathrm{c} p} \leq 0.001$, and ${ }^{\mathrm{d}}$ non significant. Groups III and IV are compared with Group II, where ${ }^{\mathrm{e}} \mathrm{p} \leq 0.05,{ }_{\mathrm{f}}^{\mathrm{p}} \leq 0.01,{ }^{\mathrm{g}} \mathrm{p} \leq 0.001$, and ${ }^{\mathrm{h}}$ non significant. SEM: Standard error of the mean. PTU: 6-n-propyl-2-thio-uracil, W. somnifera: Withania somnifera

Table 2: Comparative analysis of various parameters of RFT in all groups

\begin{tabular}{llll}
\hline Group name & Urea (mg/dL) & Creatinine (mg/dL) & Uric acid (mg/dL) \\
\hline Group I (control) & $36.33 \pm 3.63$ & $0.96 \pm 0.08$ & $4.16 \pm 0.48$ \\
Group II (PTU treatment) & $47.36 \pm 3.27^{\mathrm{b}}$ & $1.06 \pm 0.1^{\mathrm{a}}$ & $15.36 \pm 1.38^{\mathrm{c}}$ \\
Group III (W. somnifera leaf extracts & $35.66 \pm 3.61^{\mathrm{d}, \mathrm{h}}$ & $0.8 \pm 0.08^{\mathrm{d}, \mathrm{h}}$ & $4.63 \pm 0.3^{\mathrm{d}, \mathrm{h}}$ \\
treatment) & $36.56 \pm 3.56^{\mathrm{d}, \mathrm{h}}$ & $0.92 \pm 0.06^{\mathrm{a}, \mathrm{h}}$ & $3.35 \pm 0.46^{\mathrm{d}, \mathrm{h}}$ \\
Group IV (Eltroxin treatment) & 3
\end{tabular}

Values expressed as mean \pm SEM ( $\mathrm{n}=5)$. Groups II-IV compared with Group I, where ${ }^{\mathrm{a}} \mathrm{p} \leq 0.05,{ }^{\mathrm{b}} \mathrm{p} \leq 0.01,{ }^{\mathrm{c}} \mathrm{p} \leq 0.001$, and ${ }^{\mathrm{d}}$ non significant. Groups III and IV are compared with Group II, where ${ }^{\mathrm{e}} \mathrm{p} \leq 0.05,{ }^{\mathrm{f}} \mathrm{p} \leq 0.01,{ }^{\mathrm{g}} \mathrm{p} \leq 0.001$, and ${ }^{\mathrm{h}}$ non significant. SEM: Standard error of the mean. W. somnifera: Withania somnifera, RFT: Renal function test

Table 3: Comparative study of various parameters of LFT in all groups

\begin{tabular}{|c|c|c|c|c|c|}
\hline Group name & $\begin{array}{l}\text { Bilirubin total } \\
(\mathrm{mg} / \mathrm{dL})\end{array}$ & $\begin{array}{l}\text { Bilirubin direct } \\
\text { (mg/dL) }\end{array}$ & $\begin{array}{l}\text { Bilirubin } \\
\text { indirect }(U / L)\end{array}$ & SGOT (U/L) & SGPT (U/L) \\
\hline Group I (control) & $0.49 \pm 0.037$ & $0.13 \pm 0.012$ & $0.32 \pm 0.02$ & $37.66 \pm 3.26$ & $35.1 \pm 3.58$ \\
\hline Group II (PTU treatment) & $0.70 \pm 0.05^{\mathrm{b}}$ & $0.20 \pm 0.018^{\mathrm{b}}$ & $0.27 \pm 0.025^{c}$ & $148.3 \pm 10.15^{c}$ & $312.3 \pm 29.18^{c}$ \\
\hline $\begin{array}{l}\text { Group III (W. somnifera leaf extract } \\
\text { treatment) }\end{array}$ & $0.86 \pm 0.077^{\mathrm{c}, \mathrm{h}}$ & $0.51 \pm 0.027^{c, g}$ & $0.29 \pm 0.021^{\mathrm{c}, \mathrm{h}}$ & $53.7 \pm 5.35^{\mathrm{a}, \mathrm{g}}$ & $41.05 \pm 4.66^{\mathrm{d}, \mathrm{g}}$ \\
\hline Group IV - (Eltroxin treatment) & $0.59 \pm 0.049^{\mathrm{a}, \mathrm{h}}$ & $0.12 \pm 0.011^{\mathrm{d}, \mathrm{f}}$ & $0.37 \pm 0.024^{\mathrm{c}, \mathrm{f}}$ & $134.55 \pm 11.88^{c, e}$ & $73.85 \pm 5.86^{c, g}$ \\
\hline
\end{tabular}

Values expressed as mean \pm SEM (n=5). Groups II-IV compared with Group I, where ${ }^{\mathrm{a} p} \leq 0.05,{ }^{\mathrm{b}} \mathrm{p} \leq 0.01,{ }^{\mathrm{c}} \mathrm{p} \leq 0.001$ and ${ }^{\mathrm{d}}$ non significant. Groups III and IV are compared with Group II, where ${ }^{\mathrm{e}} \mathrm{p} \leq 0.05$, ${ }^{\mathrm{f}} \mathrm{p} \leq 0.01$, ${ }^{\mathrm{g}} \mathrm{p} \leq 0.001$ and ${ }^{\mathrm{h}}$ non significant. SEM: Standard error of the mean. SGPT: Serum glutamic pyruvic transaminase, LFT: Liver function test, SGOT: Serum glutamic oxaloacetic transaminase, W. somnifera: Withania somnifera

Table 4: Comparative study of other parameters in blood serum of the rats in all groups

\begin{tabular}{lllllll}
\hline Group name & $\begin{array}{l}\text { Blood sugar } \\
\text { (mg/dL) }\end{array}$ & $\begin{array}{l}\text { Cholesterol } \\
\text { (mg/dL) }\end{array}$ & $\begin{array}{l}\text { Alkaline } \\
\text { phosphate (U/L) }\end{array}$ & $\begin{array}{l}\text { Protein } \\
\text { (g/dL) }\end{array}$ & $\begin{array}{c}\text { Albumin } \\
\text { (mg/dL) }\end{array}$ & $\begin{array}{c}\text { Globulin } \\
\text { (mg/dL) }\end{array}$ \\
\hline $\begin{array}{l}\text { Group I (control) } \\
\text { Group II (PTU treated) }\end{array}$ & $79 \pm 5.77$ & $75.7 \pm 6.7$ & $250.73 \pm 25.28$ & $6.73 \pm 0.46$ & $2.8 \pm 0.2$ & $3.9 \pm 0.34$ \\
$\begin{array}{l}\text { Group III-W. somnifera leaf extract } \\
\text { treatment }\end{array}$ & $121.26 \pm 11.283^{\mathrm{b}}$ & $151 \pm 3.46^{\mathrm{c}}$ & $121.75 \pm 13.7^{\mathrm{c}}$ & $5.38 \pm 0.43^{\mathrm{d}}$ & $2.19 \pm 0.21^{\mathrm{a}}$ & $2.17 \pm 0.15^{\mathrm{c}}$ \\
Group IV - (Eltroxin treatment) & $91.12 \pm 8.24^{\mathrm{d}, \mathrm{h}}$ & $72.86 \pm 4.42^{\mathrm{d}, \mathrm{e}}$ & $349.6 \pm 12.41 \mathrm{~b}, \mathrm{~g}$ & $7.36 \pm 0.58^{\mathrm{d}, \mathrm{h}}$ & $3.08 \pm 0.36^{\mathrm{d}, \mathrm{e}}$ & $4.2 \pm 0.34^{\mathrm{d}, \mathrm{g}}$ \\
\hline
\end{tabular}

Values expressed as mean \pm SEM ( $n=5$ ). Group II-IV compared with Group I, where ${ }^{\mathrm{a}} \mathrm{p} \leq 0.05,{ }^{\mathrm{b}} \mathrm{p} \leq 0.01,{ }^{\mathrm{c}} \mathrm{p} \leq 0.001$ and ${ }^{\mathrm{d}}$ non significant. Groups III and IV are compared with Group II, where ${ }^{\mathrm{e}} \mathrm{p} \leq 0.05,{ }^{\mathrm{f}} \mathrm{p} \leq 0.01,{ }^{\mathrm{g}} \mathrm{p} \leq 0.001$, and ${ }^{\mathrm{h}}$ non significant. SEM: Standard error of the mean, W. somnifera: Withania somnifera

cholesterol level observed in blood serum of PTU treated the group as compare to control whereas Groups III and IV exhibited no changes or slightly changes as compared to control in blood sugar and serum cholesterol. There were no significant changes observed in protein during experimentation (Table 4).

\section{Hematology profile}

All parameter of hematology was calculated when compared with control (Table 5).

\section{DISCUSSION}

The thyroid gland is a small but most important gland in the mammalian body; it plays a pivotal role in overall body function and homeostasis.
Thyroid gland secret $93 \%$ of the thyroxine $\left(\mathrm{T}_{4}\right)$ which is a metabolically inactive hormone and $7 \%$ tri-iodothyronine $\left(\mathrm{T}_{3}\right)$ although later on almost all thyroxin is converted in tri-iodothyronine [16]. Thyroid hormone exerts a broad range of effects on growth, metabolism, and development. The medical manifestations of thyroid hormone excess or deficiency are remarkable examples of the innumerable actions of the hormone. The primary secretions of the thyroid are thyroxine $\left(\mathrm{T}_{4}\right)$ which are relatively inactive and are converted to the active hormone, tri-iodothyronine $\left(\mathrm{T}_{3}\right)$, by the enzyme thyroxine 5 '-deiodinase [17]. In the present study, PTU was used to induce hypothyroidism in rats. PTU blocks the oxidative iodinationation in the thyroid gland so that thyroid hormone-like thyroxine $\left(\mathrm{T}_{4}\right)$ and tri-iodothyronine $\left(\mathrm{T}_{3}\right)$ level decrease in serum [18], in the present investigation, we have reported similar findings. Synthetic drug Eltroxin which is commonly used at 
Table 5: Comparison of various hematological parameters in all groups

\begin{tabular}{|c|c|c|c|c|}
\hline Group name & $\begin{array}{l}\text { Group I } \\
\text { (control) }\end{array}$ & $\begin{array}{l}\text { Group II } \\
\text { (PTU treatment) }\end{array}$ & $\begin{array}{l}\text { Group III } \\
\text { (W. somnifera leaf extract treatment) }\end{array}$ & $\begin{array}{l}\text { Group IV } \\
\text { (Eltroxin treatment) }\end{array}$ \\
\hline Hemoglobin (g\%) & $12.6 \pm 0.63$ & $13.5 \pm 1.26$ & $11.46 \pm 0.5$ & $13.13 \pm 0.7$ \\
\hline $\mathrm{TRBC}\left(\mathrm{mil} / \mathrm{mm}^{3}\right)$ & $7.08 \pm 0.51$ & $4.25 \pm 0.33$ & $4.26 \pm 0.32$ & $6.18 \pm 0.52$ \\
\hline HCT (\%) & $37.06 \pm 2.32$ & $23.6 \pm 2.23$ & $38.46 \pm 1.89$ & $23.6 \pm 2.2$ \\
\hline MCV (fL) & $52.53 \pm 5.29$ & $54 \pm 5.98$ & $88.63 \pm 6$ & $54.56 \pm 4.63$ \\
\hline MCH (pg) & $17.76 \pm 1.18$ & $18.6 \pm 1.05$ & $23.93 \pm 0.8$ & $17.7 \pm 1.18$ \\
\hline MCHC (g/dL) & $33.8 \pm 3.04$ & $36.46 \pm 3.58$ & $26.6 \pm 1.96$ & $33.63 \pm 1.02$ \\
\hline $\operatorname{TLC}\left(\mathrm{th} / \mathrm{mm}^{3}\right)$ & $10,053 \pm 611.91$ & $7883.33 \pm 692.69$ & $5633.33 \pm 837.32$ & $6883.33 \pm 697.53$ \\
\hline Neutrophil & $10.66 \pm 1.76$ & $16.66 \pm 1.84$ & $38.66 \pm 3.45$ & 8.63 \\
\hline Lymphocyte & $76 \pm 2.43$ & $65 \pm 4.72$ & $66 \pm 5.5$ & $8 \pm 0.5$ \\
\hline Monocyte & $6.9 \pm 0.39$ & $10.66 \pm 1.16$ & $4.56 \pm 0.34$ & $11.33 \pm 1.17$ \\
\hline Eosinophil & $4.6 \pm 0.305$ & $3.3 \pm 0.38$ & $8 \pm 0.5$ & $5 \pm 0.53$ \\
\hline \multirow[t]{2}{*}{ PLT } & $4.35 \pm 0.32$ & $2.31 \pm 0.28$ & $3.1 \pm 0.32$ & $3.51 \pm 0.30$ \\
\hline & lacs/cummm & lac/cumm & lac/cumm & lac/cumm \\
\hline PCT & $0.27 \pm 0.02$ & $0.16 \pm 0.015$ & $0.24 \pm 0.02$ & $0.22 \pm 0.02$ \\
\hline PDW & $9.5 \pm 0.5$ & $9.76 \pm 0.55$ & $8.13 \pm 0.84$ & $7.5 \pm 0.6$ \\
\hline
\end{tabular}

PLT: Platelet count, MPV: Mean platelet volume, W. somnifera: Withania somnifera

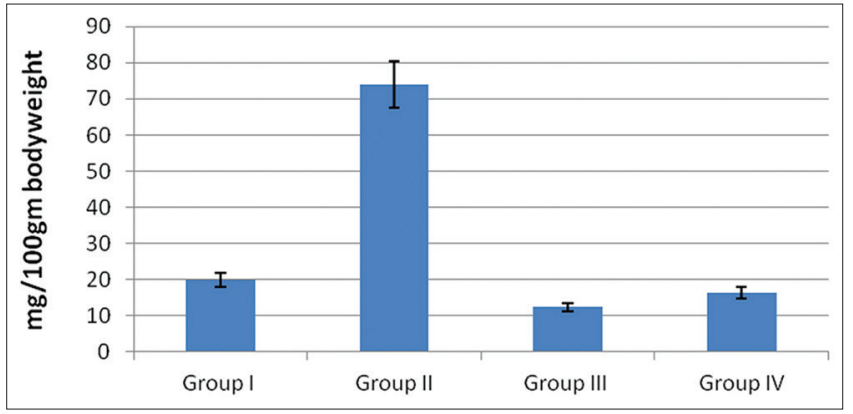

Fig. 3: Thyroid weight of rats in various experimental groups. Values expressed as mean $\pm \operatorname{SEM}(n=5)$. Groups IIIV compared with Group I, where ${ }^{\mathrm{a}} \mathrm{p} \leq 0.05,{ }^{\mathrm{b}} \mathrm{p} \leq 0.01,{ }^{\mathrm{c}} \mathrm{p} \leq 0.001$, and $^{\mathrm{d} n o n}$ significant. Groups III and IV are compared with Group II, where ${ }^{\mathrm{e}} \mathrm{p} \leq 0.05,{ }^{\mathrm{f}} \mathrm{p} \leq 0.01,{ }^{\mathrm{g}} \mathrm{p} \leq 0.001$, and ${ }^{\mathrm{h}}$ non significant. SEM -Standard error of the mean

the different dosage to control hypothyroidism in human being shows a significant increase of $\mathrm{T}_{4}$ and $\mathrm{T}_{3}$ level. In the present investigation, Eltroxin was used as a standard drug which causes significant improvement in $\mathrm{T}_{3}$ and $\mathrm{T}_{4}$ level in hypothyroid rats. Similar findings have been reported by plant-like W. somnifera and Bauhinia purpurea in female mice [19]. This is mainly due to changing the inactive hormone to active hormone $[20,21]$. The green medicine $(W$. somnifera's leaf extract) can also increase the level of $\mathrm{T}_{3}$ and $\mathrm{T}_{4}$ in the experimental group without any side effects. This is mainly due to beneficial effects of plant extract on the thyroid gland. The improvement of $\mathrm{T}_{3}$ and $\mathrm{T}_{4}$ suggests that plant extract possesses $\mathrm{T}_{3}$ and $\mathrm{T}_{4}$ like compound, which mimics like Eltroxin [22,23]. Some plants show thyroid stimulating actions [24] and suggested that green medicines positively effect on serum $\mathrm{T}_{3}$ and $\mathrm{T}_{4}$. Besides this, they increase the hepatic glucose-phosphate activity and hepatic-lipid-peroxidase activity [25]. In the present investigation, increase of glucose was reported in blood and abnormal function of kidney and liver by PTU treatment. This is mainly due to the adverse effect of PTU on the vital organs. In the present investigation when the plant extract was given to PTU induced hypothyroid rats, all these parameters come to the normal range which shows a beneficial effect of W. somnifera leaf extract in controlling hypothyroid without showing any toxicity on liver and kidney. These findings reported by a different scientist on plant product which shows low toxicity of green medicine [26]. The current study indicates that the plant extracts are having no toxicity which is reflecting in hematology. All parameters of hematology in treatment groups were within the normal range. The current study recommends that $W$. somnifera extract can cure hypothyroidism without causing any adversity on the vital organ as well as on hematology.

\section{CONCLUSION}

The present finding reveals that $W$. somnifera leaf extract can control the hypothyroidism. It normalize the $\mathrm{T}_{3}$ and $\mathrm{T}_{4}$ level in blood serum. Moreover, it does not show any toxicity in any of the LFT and RFT parameters and hematology of the rat's blood.

\section{ACKNOWLEDGMENT}

We would like to acknowledge Head of the Department of Zoology, Jai Narain Vyas University, Jodhpur (Rajasthan), for providing all necessary amenities.

\section{AUTHOR CONTRIBUTION}

The complete research work was suggested and designed by Ashok Purohit. All experiments were carried out by Abhilasha Purohit. Authors drafted and approved the final manuscript.

\section{CONFLICTS OF INTEREST}

The authors declare that they have no conflicts of interests.

\section{REFERENCES}

1. Mahmoud GS, Abd EL-Aziz AE, Muhammed AA. The protective effect of Garcinia on cardiovascular system of propylthiouracil induced hpothyroid rat. IOSR J Dent Med Sci 2016;15:103-12.

2. Korac A, Milosevic MC, Davidovic V. Methimazole-induced hypothroidism in rats: Effects on body weight and histological charactersticis of thyroid gland. Jugoslov Med Biochem 2004;23:143-7.

3. Oncu M, Kanter M, Gokcimen A, Kavakli D, Oncu M, Ural M. Effect of thyroidectomy on the histology of rat sublingual gland. APMIS 2004;112:119-22.

4. Bacova BS, Viczenczova C, Benova TE, Soukup T, Rauchova H, Pavelka, S, et al. Cardiac connexin-43 and PKC signaling in rats with altered thyroid status without and with omega-3 fatty acids intake. Physiol Res 2016;65:S77-90.

5. Silva JE. Thyroid hormone control of thermogenesis and energy balance. Thyroid 1995;5:481-92.

6. Hebbar S, Kumar S, Amin S, Doizode S. Subclinical hypothyroidism in pregnanacy; Is there a need for pharmacological intervention? Int $\mathrm{J}$ Pharm Pharm Sci 2017;9:186-191.

7. Ezz MK, Hassan RE, Esmat AY. Pineapple juice supplementation activates thyroid gland and attenuates hyperlipidemia in rats. Int $\mathrm{J}$ Biosci 2017;10:173-84.

8. Nakamura H, Noh JY, Itoh K, Fukata S, Miyauchi A, Hamada N. 
Comparison of methimazole and propylthiouracil in patients with hyperthyroidism caused by Graves' disease. J Clin Endocrinol Metab 2007;92:2157-62.

9. Sinha S, Chakraborty A, Mondal C, Chandra AK. Effect of Vitamin acetate supplementation on thyroid hormone-sensitive organs following exogenous L-thyroxine treatment. Asian J Pharm Clin Res 2018;11:123-9.

10. Sarkar D, Chakraborty A, Bhattacharya C, Singh LH, Chandra AK. Exploration of Goitrogenic/antithyroidal potentiality of bamboo-shoots in relation to Thioura. Int J Pharm Pharm Sci 2017;9:7-12.

11. Panda S, Kar A. Guggulu (Compiphora mukul) potentially ameliorates hypothyroidism in female mice. Phytother Res 2005;19:78-80.

12. Purohit A, Vyas KB. Hypolipidaemic efficacy of Capparis decidua fruit and shoot extract in cholesterol fed rabbits. Indian J Exp Biol 2005;43:863-6.

13. Tripathi P, Singh A. Natural resources from plants in the treatment of cancer: An update. Asian J Pharm Clin Res 2017;10:172-81.

14. Verma SK, Kumar A. Therapeutic uses of Withania somnifera (Ashwgandha) with a note on withanolids and its pharamacological actions. Asian J Pharm Clin Res 2011;4:1-4.

15. Wintrobe WM. In: Greer JP, Wintrobe MM, editors. Wintrobe's Clinical Hematology. $12^{\text {th }}$ ed. USA: Lippincott Williams \&Wilkins Health; 2011. p. 121-225.

16. Alkalby JM, Alzerjawi SJ. Effect of propylthiouracil-induced hypothyroidism on reproductive efficiency of adult rats. Bas J Vet Res 2013;12:113-21.

17. Breant GA. The molecular basis of thyroid hormone action. N Engl J
Med 1994;331:847-53.

18. Geffner LD, Azukizawa M, Hershman JM. Propylthiouracil blocks extrathyroidal conversionof thyroxine to triiodthyronine. J Clin Invest 1975;55:224-9.

19. Panda S, Kar A. Withania somnifera and Bauhinia purpurea in the regulation of circulating thyroid hormone concentrations in female mice. J Ethnopharmacol 1999;67:233-9.

20. Griffen EE, Miller LL. Efects of hpothyroidism, hyperthyroidism, and thyroxine on net synthesis of plasma proteins by the isolated perfused rat liver. J Biol Chem 1972;248:4716-23.

21. Bindu N, Kenneth B. Thyrotoxicosis and thyroid stor. Endocrinaol Metab Clin North Am 2006;35:663-86.

22. Chadha R, Purohit A. Wheat bran extract mimics statin like action in hyperlipidemic rabbits: An experimental study. Asian J Pharm Clin Res 2018;11:402-5.

23. Jatwa R, Kar A. Amelioration of metformin-induced hypothyroidism by Withania somnifera and Bauhinia purpurea extracts in Type 2 diabetic mice. Phytother Res 2009;23:1140-5.

24. Kar A, Panda S. Relative efficacy of three medicinal plant extracts in the alteration of thyroid hormone concentration in male mice. J Ethnopharmacol 2002;81:281-5.

25. Panda S, Kar A. Changes in thyroid hormone concentrations after administration of Ashwagandha root extract to adult male mice. J Pharm Pharmacol 1998;50:1065-8.

26. Panda S, Kar A. Withania somnifera and Bauhinia purpurea in the regulation of circulating thyroid hormone concentration in female mice. J Ethnopharmacol 1999a;67:233-9. 